\title{
On Mencius' Key Philosophical Term: Yi C-E Translation in the Perspective of Reception Theory
}

\author{
Lanlan Lai ${ }^{*}$, Pu Dong1, Yeye Liu1, Xiaoying Chen ${ }^{2}$ \\ ${ }^{1}$ Huizhou University, Huizhou, China \\ ${ }^{2}$ Zhanjiang People's Hospital, Zhanjiang, China \\ Email: *doublelai@126.com
}

How to cite this paper: Lai, L. L., Dong, P., Liu, Y. Y., \& Chen, X. Y. (2018). On Mencius' Key Philosophical Term: Yi C-E Translation in the Perspective of Reception Theory. Chinese Studies, 7, 277-285. https://doi.org/10.4236/chnstd.2018.74024

Received: August 13, 2018

Accepted: November 2, 2018

Published: November 5, 2018

Copyright (c) 2018 by authors and Scientific Research Publishing Inc. This work is licensed under the Creative Commons Attribution International License (CC BY 4.0).

http://creativecommons.org/licenses/by/4.0/ (c) (i) Open Access

\begin{abstract}
Mencius keeps a record of political activities, doctrine and philosophy, moral principles and educational ideology of the whole life of Mencius by way of narration and dialogue and also describes the debate over the inborn goodness of human nature, being one of the most influential classic works, which has a profound influence on Chinese philosophy. With the guidance of Reception Theory, based on the corpus of James Legge, the Library of Chinese Classics (hereafter short for LCC) and D. C. Lau's versions of Mencius, a comparative study will be conducted on the key philosophical term: $Y i$ (义). Quantitative analysis shows that $Y i$ rendered as "righteousness/righteous", which is the most widely accepted in Legge's and LCC's versions with its frequency at the times of 95 and 77 respectively, however, Lau's seems to be more various using words such as "right/rightness, duties and moral". The results show that the version of Lau's shares the same horizon of expectations with the source text while those of Legge's and LCC's with the target readers.
\end{abstract}

\section{Keywords}

Mencius, English Versions, Reception Theory, $Y i$

\section{Introduction}

Mencius keeps a record of political activities, doctrine and philosophy, moral principles and educational ideology of the whole life of Mencius by way of narration and dialogue and also describes the debate over the inborn goodness of human nature, being one of the most influential classic works, which has a profound influence on Chinese philosophy. Confucian classics are important carriers 
of traditional Chinese culture, embodying the soul of Chinese nation, so correctly translating Mencius is helpful to promote Confucian culture and traditional Chinese culture in a complete and systematic way. The government has also attached more and more importance to introducing traditional Chinese culture to the rest of the world; thus Chinese ancient classics shoulder the responsibility of carrying on and promoting Chinese culture as well as building the country's positive image. Furthermore, the translation of Chinese classics not only plays the role of promoting Chinese culture and raising our "soft power", but also directly influences overseas scholars, research and comments on Chinese culture.

\section{Literature Review}

For more than three centuries, many famous translators such as James Legge, Arthur Lyall, Lionel Giles, Arthur Waley, David Hinton, D. C. Lau as well as Zhao Zhentao, Zhang Wenting, \& Zhou Dingzhi (1999) have been devoting themselves to Mencius translation. In the past few years, study on translation of Mencius has been boosting a great prosperity. In terms of version, James Legge's and D. C. Lau's enjoy the most popularity. In terms of content, study mainly pays great attention to style and linguistic equivalence, while few on cultural factors. In terms of methodology, researchers mainly adopt comparative and qualitative methods, however, due to development of computer science and corpus, quantitative method is applied. Besides, in the perspective of theory, almost most translation and literary theories have been applied to translation appreciation.

In 1953, Peter A. Boodberg, who made a detailed study on some of primary Confucian concepts from perspective of semasiology, is the first scholar to study on the primary Confucian concepts such as Ren, Yi Li and Junzi.

Referring to CNKI and data from Yue Feng (2003) and Liu Danping (2011), the studies of the English translation of Mencius at home and abroad are as the following: from 1995-2014, there are 18 doctoral dissertations and M. A. thesis, 25 journal papers and 2 monographs from scholars in Chinese mainland; and there are 12 journal papers and 10 monographs and memoirs from overseas and Hong Kong scholars. The pioneer Chu Zhida (1995), in his article Comments on James Legge's Translation of Two Passages from Mencius, indicated that as a foreigner, Legge was insufficient in understanding the original texts and lacked some necessary Chinese background knowledge, thus there were unavoidable mistranslations in Legge's version.

Overseas scholars have also done abundant researches on the English translations of Mencius, covering the research on translators and translated versions, the comments on translated works, the discussions on key-term translation, the translation and introduction on the philosophical ideas of Mencius and the comparative study of the mode of thinking, arguments on humanity, social and political view, concept of the nature's law and conceptualism etc. between Chinese and western traditions from the angle of comparative philosophy (Liu Danping, 2011: p. 10). 
With the development of society, target readers vary greatly in cultural background, education level, age, and religion, values etc. Mencius translations no longer take academic researchers or advanced readers as their main target readers, but turn to a more diverse readers. Versions for different levels of readers have come out. Modern language, pictures, rearrangement, etc. are widely used in translations, which makes Mencius translations more readable and popular. Besides, translators' critical thinking is also put into translations, which would greatly help readers grasp the essence, key ideas, culture and philosophical thoughts implied in Mencius (Ji Hongqin, 2013).

\section{Theoretical Framework}

Hans Robert Jauss gave in his monumental essay "Literary History as a Challenge to Literary Theory" in Towards an Theory of Reception (1982), which marked the birth of Reception Theory. This theory, based on the study of reader, which will focus on opinions of two major leaders of reception theory, namely, Jauss' "horizon of expectations" and Iser's "blanks \& indeterminacy" as well as "reader's role \& status" to explore translators' creative reproduction of literary translation, poses a new way for explanation of literary translation.

The Reception Theory was accepted by some scholars at the University of Constanz in Germany in the early 1970s and then enjoyed rapid development also in European and American literature field. The Reception Theory emphasizes the central position of reader's role and status. The reader's reception of aesthetic value is attached great importance to. Together with other scholars, Hans Robert Jauss and Wolfgang Iser, two major representatives of the Constance School, admitted and declared the significantly important role of reader in literary reading in the mid-1960s. The lecture "Literary History as a Provocation to Literary Scholarship" has been recognized as the mark of the birth of Reception Theory, which has its notion grounded in Phenomenology and Hermeneutics, grounded from Husserl's theory and Heidegger's theory respectively. It focuses on reader's role and status. Iser, as another representative of the Constance School, mainly pointed out the interaction between the texts and readers, whose theoretical foundation came from Ingarden's idea-reading process, the readers' comprehension of a literary work and the relation between the texts and readers.

Reception Theory belongs to a kind of Hermeneutics in terms of methodology. Some conceptions in Hermeneutics Theory of H.G Gadamer like "pre-structure", "effect history" and "understanding of horizon" are all inherited directly in Reception Theory (Jauss, 1982: p. 3). Just as Paul de Man has pointed out in the preface of Toward an Aesthetic of Reception that: "Reception Theory is literary Hermeneutics." Based on the study of reader, which will mainly discuss Jauss' "horizon of expectations" to explore translators' creative reproduction of literary translation. Analysis from this perspective will be made, taking $Y i$ as an example to elaborate. 
Reception Theory enables a text not simply passively accepted by the audience, but also allows the receptor interprets the meanings of the text based on their individual cultural background and life experiences.

\section{Case Analysis and Discussion}

$Y i$, justice or righteousness, being on the list of traditional Chinese virtues, has become the morality and standard of values, which mainly handles the relation between the monarch and his subjects after the inheritance and development of the virtues of respecting wisdom, justice, fairness, selflessness in the dynasties of Zhou and Shang. Its purpose was to practice the highest moral standard of Ren. Hence, Ren and $Y i$ are always bound together in Confucianism. Ren is internal, not external; $Y i$ is external, not internal."(Mencius 6BC4)

In the perspective of etymology, an interesting part of this character can be seen is that the evolution of this character $Y i$ (义一義) could be traced down to the animal sheep or goat. “義” is the original complex character of “义”. “義” can be separated into the upper part “羊 (sheep or goat)", which represents the sound and indicates some meaning, and the lower part "我 (I)", which shows the form. It is a phonogram, or picto-phonetic character and an ideogram, or associative compound character. More than two thousand years ago, when the Chinese character was still in the ancient period of inscriptions on the oracles, that is the inscriptions on bones or tortoise shells of the Shang Dynasty from 16 th to 11 th century B.C., the character of $Y i$ had already been shaped like this. Figure 1 is the character's evolution chart.

It forms an image of a broad axe with its axe edge facing the left. The original meaning of “我” stands for, in most cases a broad axe, a tool or weapon used for criminal purposes, either to kill people or dismember the draught animals. The extended meaning of “我” thus developed into "kill or massacre". We can easily identify the image of putting a broad axe towards a ram from the bell-cauldron inscription of “义”, which we also call inscriptions on ancient bronze objects in the $Y$ in-Zhou dynasty, being the first character on the second line starting from the left. The form of "我” first took shape in the small-seal style which is a style of calligraphy adopted in the Qin Dynasty for the purpose of standardizing the script. It is the character in the middle on the first line in the chart.

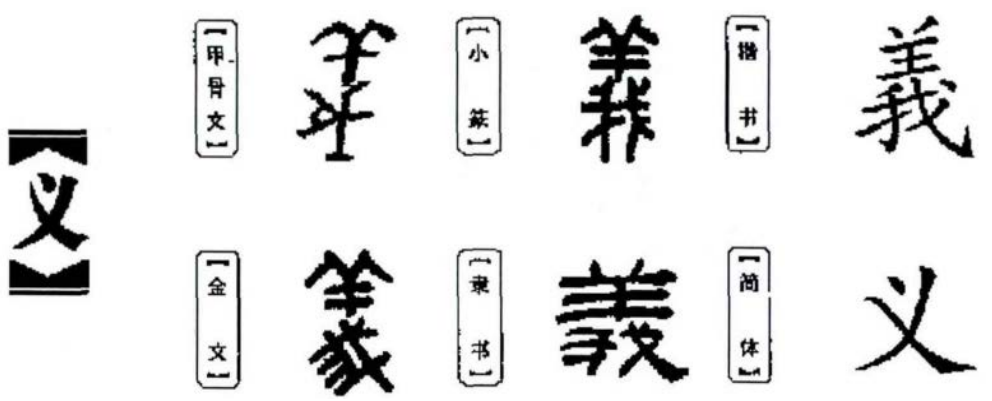

Figure 1. Yi, the character's evolution chart (Xianzhuangjingdian, 2010: p. 335). 
Through a long period of accumulated life experience of the habit of ram, people discovered that in order to defend their leadership or authority and the priority to mate in their ethnic groups, those stronger and healthier rams always engage themselves in mortal combats with their challengers, or with the attempt to safeguard the interests of its ethnic group. Hence, the character “羊” and “我” are combined together to form the character “義” and make up the original meaning of $Y i$ which is "the fight or battle of a ram with the purpose of defending himself or its leadership in its ethnic group". As such kind of battle is out of a legitimate and justified reason, the meaning of $Y i$ later evolved into "go on a punitive expedition or wage a war under a justified reason". Then the character $Y i$ once again evolved into a word which is endowed with the meanings of justice, righteousness, fair and proper ethics, morality and principles, etc.

Mengzi argues that Ren motivates us to love others, and that $Y i$ motivates us to fulfill our moral duties to others. Ren and $Y i$ enable us to follow the Dao. If we act benevolently and righteously, then we can follow the Dao. The core of $Y i$ is obeying one's elder brother. $Y i$ is a disposition to disdain or regard as shameful dishonorable behavior or demeaning treatment. As is the case with benevolence, righteousness has cognitive and behavioral aspects. Thus, a righteous person would object to being addressed disrespectfully (7B31), and would not engage in an illicit sexual relationship (3B3). A fully righteous person would also recognize that it is just as shameful to accept a large bribe as it is to accept a small bribe (6A10), and so would refuse to accept either. ${ }^{1}$

$Y i$ is often rendered as righteousness, but this, though close enough and equivalent, lacks the versatility of the Chinese word. $Y i$ can be applied to an act which is right, to the agent who does what is right and to a duty which an agent ought to do. According to Ancient Chinese Dictionary, a deed or matter that accords with justice or righteous.

According to the data collection from the original text and its three English versions, findings are shown in Table 1.

According to Yang Bojun(1988), $Y i$ appears altogether 108 times, including in the form of phrases such as "renyi" (仁义) twenty-four times, “zhiyi" (之义) six times and "liyi" (礼义) five times etc., while the opposite one includes 10 times. From the above statistics, it can be found that "righteousness/righteous" is the most widely translated in Legge's and LCC's versions with its frequency at the times of 95 and 77 respectively, however, Lau's seems to be more various using words such as "right/rightness, duties and moral". For the original text, $Y i$ has two most basic meaning: doing in accordance with a certain "Dao" with a number of 98 times and truth or principle with the number of ten times.

Combined with the quantitative research methodology, qualitative research is adopted to make it more explicit. Samples are extracted from the parallel corpus. From Table 1, it is shown that in most cases $Y i$ is translated as "righteous/righteousness" both in James's and LCC's versions, however, "right/rightness,

${ }^{1}$ https://plato.stanford.edu/entries/mencius/ 
Table 1. Yi and $\mathrm{Bu}$ (not) $Y i$ Translation in Three Versions.

\begin{tabular}{ccccccc}
\hline & $\begin{array}{c}\text { (Un)Righteous } \\
\text { Righteousness }\end{array}$ & $\begin{array}{c}\text { (Un)right } \\
\text { Rightness }\end{array}$ & Principle & Duties & Morality & Ill-gotten \\
\hline James Legge & 95 & 4 & 2 & 2 & 0 & 0 \\
D. C. Lau & 0 & 42 & 2 & 34 & 23 & 2 \\
LCC & 77 & 3 & 5 & 4 & 0 & 3
\end{tabular}

Note: James Legge's version is omitted two times; Lau's uses "wrong" two times and "ground, integrity and significance" once; however, LCC's seems to be more varied with "point, nature, why, how good means, wrong, unjustifiable, rites and foul" once.

duties or morality in that of Lau". Therefore, the-above most frequent words are discussed and analyzed in this part. A careful study of English dictionaries is needed to help explore the reasons for their different interpretations. Examples help to analyze the differences in the perspective of Reception Theory are as follows:

1) 谨痒序之教, 申之以孝悌之义, 颁白者不负戴于道路矣。(1AC7)

James' version: Let careful attention be paid to education in schools, - the inculcation in it especially of the filial and fraternal duties, and grey-haired will not be seen upon the roads, carrying burdens on their backs or on their heads (James, 1991).

LCC's version: Let careful attention be paid to education in local schools, where the significance of filial and fraternal duties is stressed repeatedly, and grey-haired people will not be carrying loads on the roads (Zhao Zhentao et al., 1999).

Lau's version: Exercise due care over the education provided by village schools, and reinforce this by teaching them duties proper to sons and younger brothers, and those whose heads have turned hoary will not be carrying loads on the roads (Lau, 2004).

This sentence shows us a very harmonious scene that people can live a peaceful life with youngsters under instruction in local schools and grey-haired people not carrying loads on the roads, which can only be realized through a Kingly Way. The three translators all think that $Y i$ in the phrase “申之以孝悌之义” bears the meaning of "duties", which contains the meaning of "obligation and responsibility", however, according to Yang Bojun (1988), Yi in this phrase should be rendered as "truth or proper principle". All the versions probably cannot help readers reconstruct the true connotation of $Y i$.

According to Merriam-Webster dictionary, duty bears the three basic meanings: 1) conduct due to parents and superiors: respect; 2) obligatory tasks, conduct, service, or functions that arise from one's position; 3) a moral or legal obligation. It can be seen that duty refers to moral or legal obligation. Based on Wikipedia, duty is a term that conveys a sense of moral commitment to someone or something. The moral commitment is the sort that results in action, and it is not a matter of passive feeling or mere recognition. When someone recognizes a duty, the person commits himself/herself to the cause involved without consi- 
dering the self-interested courses of actions that may have been relevant previously. This is not to suggest that living a life of duty precludes one from the best sort of life, but duty does involve some sacrifice of immediate self-interest.

2) 苟为先义而后利, 不夺不厌。未有仁而遗其亲者也, 未有义而后其君者 也。(1AC1)

James' version: But if righteousness be put last, and profit be put first, they will not be satisfied without snatching all. There never has been a benevolent man who neglected his parents. There never has been a righteous man who made his sovereign an after consideration (James, 1991).

LCC's version: But if profits comes first and righteousness second, the killers will not be satisfied without seizing possession of whatever they covet. No benevolent man ever neglects his parents, and no righteous man ever looks down upon his sovereign (Zhao Zhentao et al., 1999).

Lau's version: Yet if profit is put before rightness, there is no satisfaction short of total usurpation. No benevolent man ever abandons his parents, and no dutiful man ever puts his prince last (Lau, 2004).

In Book 1, Ren and $Y i$ are Mencuis' only topics with the Kings of his time and the only principles which can make a country prosperous. The dialogue between Mencius and King of Liang indicates that Ren and $Y i$ are supposed to result from the sovereign's example. Both the two $Y i$ are used as a noun, the first refers to its abstract meaning while the second one refers to the concrete meaning implying a man. Compared with the three versions, James and LCC both choose "righteous/righteousness" while Lau interpret as "rightness and duty".

The definition of "righteous/righteousness" in Merriam-Webster dictionary is that: 1) acting in accord with divine or moral law; 2) morally right or justifiable; 3) arising from an outraged sense of justice or morality. Compared with those definitions, it can be concluded that to perform righteous duties means to behave according to criteria which are morally right, fair and justifiable. When we trace back the righteous: This very important term is often mentioned in the Bible. In 2 Corinthians 6:14, for example, Paul states that all non-Christians are "unrighteousness". Unfortunately, the word has three somewhat different meanings. A person: acting according to divine law, or who is free from sin, or consistently exhibits moral behavior. Of course, an individual may be acting according to divine law, be free from sin, and be moral, within the standards of one religion, but not by another. ${ }^{2}$

According to definition given by the Project to Share Key Concepts in Chinese Thought and Culture, the basic meaning of $Y i(义)$ is "reasonable" and "proper". It has two extended meanings. One is the proper basis and standard for people's actions. The other is to adjust one's words or deeds to meet certain standards, under the guidance of moral judgments. Scholars in the Song Dynasty used $L i$ (理) or "principles of heaven" to interpret $Y i$, and considered $Y i$ to be the reasonable standard defined by the "principles of heaven," and hoped that people's ${ }^{2}$ https://biblehub.com/revelation/22-11.htm

${ }^{3}$ http://www.chinesethought.cn/EN/shuyu_show.aspx?shuyu_id=2140 
words and deeds would fall in line with the "principles of heaven".

Legge was a missionary, deeply influenced by the Christian theology and God. In this sense, it is concluded that target readers can quickly connect the word "righteous/righteousness" to Bible, but it does not bear the same connotation as Yi.

3）仁义礼智, 非由外铩我也, 我固有之也, 弗思耳矣。(6AC6)

James' version: Benevolence, righteousness, propriety, and knowledge are not infused into us from without. We are certainly furnished with them (James, 1991).

LCC' version: Benevolence, righteousness, decorum, and wisdom are not conferred on me by others, they are in my essence (Zhao Zhentao et al., 1999).

Lau's version: Benevolence, dutifulness, observance of the rites, and wisdom do not give me a lustre from the outside; they are in me originally (Lau, 2004).

Ren-Yi-Li-Zhi (仁、义、礼、智) is one of the most important concepts in Mencius. Humans are born with four sprouts or seeds ["concern for others", sense of shame, "sense of humility," and "sense of right and wrong" (2A:6)] that will develop into four virtues (Ren, $Y i, L i, Z h i$ ) unless the organic process of development does not proceed. Mencius compares this to being born with four limbs. Human nature is originally good. Self-cultivation is essential. There is a relationship between the seed theory and Mencius' ideas about capacity and non-effort.

Renyi (仁义) is always rendered as a phrase for "morality", however, there are only two exceptions with the four sprouts in a phrase, so it is translated separately. Mencius is a typical parallel prose style with elegant diction and figurative language. It is not proper to give definite positive or negative opinions for the filling of blanks of original text. Chinese prose emphasizes the indeterminacies or blanks as well as the implicit beauty of the text. Therefore the blanks or gaps sometimes should be left for the readers to fill. In this way, reader's creative horizon of expectations and initiative will be inspired and satisfied.

The process of translation involves not only a working acquaintance with two languages. Translation contains the transfer of "meaning" contained in one set of language signs into another set of language signs through competent use of the dictionary and grammar, the process also involves a whole set of extra-linguistic criteria.

\section{Conclusion}

In conclusion, Reception Theory attaches great importance to the readers' initiative. The realization of the text value involves the readers' opinions. The traditional translation process of "original text-translator-translated text" needs to be reanalyzed and add readers' initiatives. Quantitative analysis shows that $Y i$ rendered as "righteousness/righteous" is the most widely accepted in Legge's and LCC's versions with its frequency at the times of 95 and 77 respectively, however, Lau's seems to be more various using words such as "right/rightness, duties 
and moral". The results show that the version of Lau's shares the same horizon of expectations with the source text while those of Legge's and LCC's with the target readers.

\section{Conflicts of Interest}

The authors declare no conflicts of interest regarding the publication of this paper.

\section{References}

Boodberg, A. P. (1953). The Semasiology of Some Primary Confucian Concepts. Philosophy East and West, 2, 317-332. https://doi.org/10.2307/1397493

Chu Zhida (1995). Comments on James Legge's Version of Mencius. Chinese Translators Journal, 5, 26-28.

James, L. (1991). Trans. The Works of Mencius. Taipei: SMC Publishing Inc.

Jauss, H. R. (1982). Towards an Aesthetic of Reception. Minneapolis, MN: University of Minnesota Press.

Ji Hongqin (2013). On the Translation of Mencius. International Proceedings of Economics Development \& Research, 12, 54-57.

Lau, D. C. (2004). Tran, Mencius (revised edition). London: Penguin Classics.

Liu Danping (2011). A Comparative Study of Three Versions of Mencius. Jinan: Shandong University.

Merriam-Webster Online Dictionary. (2018). http://www.merriam-web-ster.com/

Xianzhuangjingdian (2010). Shuowen-jiezi. Kunming: Yunnan Educational Press.

Yang Bojun (1988). Mencius Annotation. Beijing: Zhonghua Book Company.

Yue Feng (2003). Bridging the East and West-A Research on the Scottish Sinologist James Legge.

Zhao Zhentao, Zhang Wenting, \& Zhou Dingzhi (1999). Mencius. Changsha: Hunan People Publishing House. 